indicate that even the small doses of prednisolone used in our short term study may adversely affect long term growth in children with mild asthma. The exact extent of the growth inhibition and its clinical relevance, however, need further study.

Despite the short study periods the variations in lower leg length during prednisolone treatment were much larger than the technical error of the knemometer. Hence in measuring changes in a physiological parameter knemometry may have the potential of being the first non-invasive method of assessing the systemic effects of exogenous steroids and may be an important alternative or adjunct to biochemical measures of the systemic effects of topical steroids.

This study was supported by a grant from the Danish Medical Research Council (12.9009)

1 Blodgett FM, Burgin L, Iezzoni D, Gribetz D, Talbot ND Effects of prolonged cortisone therapy on statural growth, skeletal maturation and prolonged cortisone therapy on statural growth, skeletal mat

2 Falliers CJ, Tan LS, Szentivanyi J Jorgensen JR, Bukantz SC. Childhood asthma and steroid therapy as influences on growth. $A m \mathcal{F}$ Dis Child 1963;105:127-37

3 Valk IM, Langhout Chabloz AME, Smals AGH, Kloppenborg PWC, Cassorla FG, Schutte EAST. Accurate measurements of the lower leg length and the ulnar length and their application in short term growth measurement. Growth 1983;47:53-66.

4 Valk IM, Langhout Chabloz AME, Van Gilst W. Intradaily variation of the human lower leg length and short term growth-a longitudinal study in fourteen children. Growth 1983;47:397-402.

Wales JKH, Milner RDG. Knemometry in assessment of linear growth. Arch Dis Child 1987;62:166-7

6 Hermanussen M, Geiger-Benoit K, Burmeister J, Sippell WG. Knemometry in childhood: accuracy and standardization of a new technique of lower leg length measurement. Ann Hum Biol 1988;15:1-16.

7 Hermansen M, Sippell WG, Valk IM. Kn:motric monitoring of early effects of human growth hormone on leg length in children with growth effects of human growth hormone on leg

8 Hermanussen M, Geiger-Benoit K, Sippell WG. Catch-up growth followin transfer from three times weekly im to daily sc administration of $\mathrm{hGH}$ deficient patients, monitored by knemometry. Acta Endocrinol 1985;109: 163-8

9 Wales JKH, Milner RDG. Knemometry as a predictor of response to somatrem in Turner's syndrome. Acta Paediatr Scand 1987;suppl 337:37-9.

10 Wit JM, Teunissen DM, Waelkens JJJ, Gervere WJ. Comparison of shortterm lower leg growth with statural growth in children treated with growth promoting substances. Acta Paediatr Scand 1987; suppl 337:40-3.

11 Hughes IA. Steroids and growth. BrMed f 1987;295:683-4.

12 Wales JKH, Milner RDG. Variation in lower leg growth with alternate day steroid treatment. Arch Dis Child 1988:63:981-3.

13 Wit JM Van Kalsbeek EJ Van Wiik-Hoek JM, Leppink GJ Assessmet the usefulness of weekly knemometric measurements in growth studies. the usefulness of weekly knemometric

14 Feinstein AR. Clinical biostatistics. St Louis: C V Mosby, 1977:320-34.

15 Hills M, Armitage P. The two-period cross-over clinical trial. Brf Clin Pharmacol 1977;8:7-20.
.

16 Murray AB, Fraser B, Hardwick DF, Pirie G. Chronic asthma and growth failure in children. Lancet 1976:ii:197-8.

17 Hauspie R, Susanne C, Alexander F. Maturational delay and temporal growt retardation in asthmatic boys. $\mathcal{F}$ Allergy Clin Immunol 1977;59:200-6.

18 Friedman M, Strang LB. The effects of corticosteroid and ACTH therapy on growth and on the hypothalamic-pituitary-adrenal axis of children. Scandinavian fournal of Respiratory Diseases 1969;suppl 68:58-69.

19 Snyder RD, Collipp PJ, Greene JS. Growth and ultimate height of children with asthma. Clin Pediatr 1967:6:389-92.

20 Falliers CJ, Szentivanyi J, McBride M, Bukantz SC. Growth rate of children with intractable asthma. Fournal of Allergy 1961;32:420-34.

21 Hermanussen M, Geiger-Benoit K, Burmeister J, Sippell WG. Periodica changes of short term growth velocity ("mini growth spurts") in human growth. Ann Hum Biol 1988; 15: 103-9.

22 Hermanussen $M$, Geiger-Benoit $K$, Sippell WG. GH deficient childre receiving $\mathrm{GH}$ replacement do not grow during intermittent infectious illness. Acta Paediatr Scand 1986;75:601-4.

23 Hermanussen M, Geiger-Benoit K, Sippell WG. "Negative growth" in anorexia nervosa assessed by knemometry. Eur F Pediatr 1987;146:561-4

24 Harter JG, Reddy WJ, Thorn GW. Studies on an intermittent corticosteroid dosage regimen. $N$ Englf Med 1963;269:591-6.

25 Byron MA, Jackson J, Ansell BM. Effect of different corticosteroid regimen on hypothalamic-pituitary-adrenal axis and growth in juvenile chronic arthritis. I R Soc Med 1983;76:452-7.

26 Kerrebiin KF, De Kroon JPM. Effect on height of corticosteroid therapy in asthmatic children. Arch Dis Child 1968;43:556-61.

27 Hermanussen M, Geiger-Benoit K, Burmeister J, Sippell WG. Can the knemometer shorten the time for growth rate assessment? Acta Paediat Scand 1987; suppl 337:30-6.

28 Hermanussen $M$, Burmeister J. Standards for the predictive accuracy of short term body height and lower leg length measurements on half annual growth rates. Arch Dis Child 1989;64:259-63.

(Accepted 15 May 1990

\title{
The epidemiology of infertility in Aberdeen
}

\author{
Allan Templeton, Cynthia Fraser, Barbara Thompson
}

Department of Obstetrics and Gynaecology, University of Aberdeen, Foresterhill, Aberdeen AB9 2ZD

Allan Templeton, $\mathrm{MD}$, professor

Cynthia Fraser, MA, research assistant

Medical Research Council, Medical Sociology Unit, Aberdeen

Barbara Thompson, PHD honorary research fellow

Correspondence to: Professor Templeton.

\section{Abstract}

Objective-To study the prevalence of infertility, both primary and secondary, outcome of pregnancy, occupation, and uptake of medical services in a total population of women from a geographically defined area.

Design-A postal questionnaire survey of an age cohort of women who had completed their fertility, and who were randomly selected from the Grampian Health Board's primary care register.

Setting-Aberdeen city district.

Subjects-1024 Women in the age group 46-50, of whom 130 had to be excluded. Of the remaining 894 women, $766(86 \%)$ responded to the questionnaire.

Main outcome measures-Response to questionnaire on pregnancy history, the length of time taken to become pregnant each time, and whether medical advice had been sought.

Results-Among the 766 women contacted, 602 $79 \%$ ) reported no difficulties in having children, 56 (7\%) had chosen not to have children, and the remaining $108(14 \%)$ had experienced infertility, defined as having difficulty in becoming pregnant for more than two years. In total $68(9 \%)$ women had primary infertility, of whom $41(5 \%)$ eventually conceived. Of the $40(5 \%)$ with secondary infertility, $23(3 \%)$ conceived. Overall, $52(7 \%)$ of the population were left with an unresolved problem of infertility. Only $67(62 \%)$ infertile women had made use of hospital services, and a further $8(7 \%)$ had consulted their general practitioners. Among those who conceived there was no difference in the proportion who sought advice compared with those who did not.

Conclusion-The overall prevalence of infertility was $14 \%$, although half of these women eventually conceived. Primary infertility was more common than secondary infertility. Only $62 \%$ of infertile women attended a hospital clinic for treatment of their infertility.

\section{Introduction}

"Even today there is very little factual information about the prevalence of infertility." As the Warnock committee observed, accurate statistics about this common and distressing condition are not available. Yet many would consider this information to be essential to our understanding of the problem and to the planning of effective services. There is no population based survey of the prevalence of infertility in the United Kingdom, although preliminary results from a small feasibility study and from a survey of general practitioner records have been reported. ${ }^{23}$ Hitherto, estimates have been derived from census data, the general household survey, ${ }^{4}$ and longitudinal studies of subsections of the population-such as women stopping contraception, presumably with the intention of becoming pregnant.

Almost all of what is known about the characteristics of infertile women has been derived from clinic based 
studies, ${ }^{8-11}$ but these studies have described only those infertile couples who have sought help, and it is not certain that they are representative of the total infertile population. Furthermore, although people are becoming more concerned about infertility and are using the services to a greater extent, ${ }^{312}$ it is not certain whether this is because of an increased incidence of infertility or merely greater expectations of treatment. A population based profile of infertility subgroups in the United States showed that women with primary infertility were more likely to seek help, as were those in higher social classes. ${ }^{13}$ Similar results were found in an early Danish study. ${ }^{14}$

We surveyed a random sample of an age cohort of women who had completed their fertility from the total population of a defined geographical area. We studied the prevalence of infertility, both primary and secondary, pregnancy outcome, occupation, and uptake of medical services. The study had the approval of the local ethical committee.

\section{Method}

A list of the names and addresses of all women who were born between 1938 and 1942 and who lived in Aberdeen city district was obtained from Grampian Health Board's primary care register. At the time of the survey all women would have been aged 46-50 and were therefore assumed to have completed their child bearing. A random sample, obtained by selecting every fifth name on the list, generated 1024 names. A simple two page questionnaire was sent to each woman, accompanied by a prepaid return envelope and a letter explaining the purpose of the survey and seeking her cooperation. The women were asked to complete the questionnaire anonymously. Information was sought about the woman's pregnancy history, the length of time taken to become pregnant each time, any infertility problems perceived by the woman, medical advice sought, and the woman's usual occupation.

When necessary, women were invited to cooperate in up to three stages - firstly, the introductory letter and questionnaire were sent to all women (1024). If after a month there had been no response to the first letter a reminder, together with another copy of the questionnaire, was sent (425). Finally, after a further month we checked the addresses of those women who had not acknowledged either letter against the electoral register and telephone directory (208). When possible, these women were contacted by telephone (89).

\section{RESPONSE}

Table I shows the responses of the women contacted at each stage of contact. Of the total sample, 130 $(12.7 \%)$ had to be excluded from the analysis. Most of these women were assumed to be no longer at the address given because either our letters were returned by the post office or they were not documented in the electoral register at that address. In addition, our

TABLE I - Number of women responding to each stage of contact

\begin{tabular}{lccccc}
\hline & \multicolumn{5}{c}{ Stages of contact } \\
\cline { 2 - 5 } & $\begin{array}{c}\text { No after } \\
\text { introductory } \\
\text { letter and } \\
\text { questionnaire }\end{array}$ & $\begin{array}{c}\text { No after } \\
\text { reminder and } \\
\text { another }\end{array}$ & $\begin{array}{c}\text { No after } \\
\text { address } \\
\text { checked and } \\
\text { telephoned }\end{array}$ & $\begin{array}{c}\text { No (\%) of } \\
\text { all stages }\end{array}$ & $\begin{array}{c}\text { \% Women } \\
\text { assumed to } \\
\text { be available }\end{array}$ \\
\hline Qutcome & 549 & 187 & 30 & $766(74 \cdot 8)$ & $85 \cdot 7$ \\
Questionnaire completed & 2 & 4 & 59 & $65(6 \cdot 4)$ & $7 \cdot 3$ \\
Questionnaire sent to wrong address & 44 & 24 & 56 & $124(12 \cdot 1)$ & \\
Ineligible subjects & 4 & 2 & 0 & $6(0 \cdot 6)$ & \\
\hline Total responding & 599 & 217 & 145 & $961(93 \cdot 9)$ & \\
Total not responding & 425 & 208 & $63^{\star}$ & $63^{\star}(6 \cdot 1)$ & $7 \cdot 0$ \\
\hline Overall total & 1024 & 425 & 208 & 1024 & \\
\hline
\end{tabular}

ॠWomen not contacted.
TABLE II-Occurrence of pregnancy in women with primary or secondary infertility and in those with no problems with infertility

\begin{tabular}{|c|c|}
\hline Type of infertility & No $(\%)$ of women \\
\hline Primary infertility only & $56(7 \cdot 3)$ \\
\hline Never pregnant & $27(3 \cdot 5)$ \\
\hline Became pregnant & $29(3.8)^{\star}$ \\
\hline Primary and secondary infertility & $12(1 \cdot 6)$ \\
\hline Not pregnant & $8(1 \cdot 1)$ \\
\hline Became pregnant & $4(0.5)$ \\
\hline Secondary infertility only & $40(5 \cdot 2)$ \\
\hline Not pregnant & $17(2 \cdot 2)$ \\
\hline Became pregnant & $23(3 \cdot 0)^{\star}$ \\
\hline Voluntary infertility & $56(7 \cdot 3)$ \\
\hline No fertility problems & $602(78 \cdot 6)$ \\
\hline Total & 766 \\
\hline
\end{tabular}

^Including two who consulted before two years.

sample included six ineligible names: in four cases dates of birth were incorrect; one woman had died; and one patient was a man. Sixty three women $(6 \cdot 1 \%)$, who as far as we could ascertain were still living at the recorded address but had not completed and returned the questionnaire, were not contacted because they could not be traced in the telephone directory. Some of the untraced numbers might have been exdirectory or recorded under a different name. Those women who had not responded to a reminder but who could be telephoned were equally divided into two categories. Firstly, there were those who did not wish to take part, who usually added that they had had no infertility problems and therefore the survey was irrelevant to them; a few, however, viewed surveys as an invasion of privacy. Secondly, there were those who agreed to complete the questionnaire if another was sent. Only two thirds, however, did complete and return this third questionnaire. The reasons given for not responding originally included being too busy, decorating, going on holiday, relative's illness, and forgetfulness; non-return of the third questionnaire was considered to be a refusal.

Of the 894 eligible women who were assumed to have been living at the recorded address, $766(85 \cdot 7 \%)$ returned a completed questionnaire. Most of these $(549(71 \cdot 7 \%))$ completed the first questionnaire, 187 $(24.4 \%)$ responded to a reminder, and the final 30 (3.9\%) responded after a telephone call and receiving a third questionnaire. Of eligible women, $65(7 \cdot 3 \%)$ refused to take part in the survey and a further 63 $(7 \cdot 0 \%)$ neither responded nor were contacted. From the evidence of those contacted by telephone, we probably would have found that many of those women who neither responded nor were contactable would not have taken part even if approached individually.

\section{Results}

Women were considered to have a problem of infertility if they had not become pregnant after trying to conceive for over two years. Also included, however, were four women who were referred for infertility investigations after trying for only 12-15 months. Primary infertility refers to the first pregnancy and secondary infertility to any subsequent pregnancy. From their history of infertility, the women were divided into four groups: a primary group - those with primary infertility, including those who then also had secondary infertility; a secondary group-those who had secondary infertility only; a voluntary groupthose who had never tried to become pregnant; and a group with no infertility problem.

\section{PREVALENCE OF INFERTILITY}

Table II shows the numbers and the outcome in each group. Of the 766 women who completed a questionaire, $602(78.6 \%)(95 \%$ confidence interval 75.7 to $81.5 \%)$ reported no difficulties in becoming pregnant 
and $56(7 \cdot 3 \%)$ said that they had chosen not to have children. The reason given by most (35) of the 56 who had never tried to become pregnant was that they had never married. Fourteen married women, however, said that they had not wanted any children; the remaining seven gave reasons of chronic illness (four), mental handicap (two), and becoming a widow at an early age (one). The other $108(14 \cdot 1 \%)$ (95\% confidence interval 11.7 to $16 \cdot 5 \%$ ) women had experienced varying degrees of difficulty in becoming pregnant. A total of $68(8.9 \%)$ women had experienced primary infertility, of whom $27(3.5 \%)$ (95\% confience interval $2 \cdot 3$ to $4 \cdot 7 \%$ ) had never become pregnant; the remaining $41(5 \cdot 4 \%)$ eventually had become pregnant, but $12(1.6 \%)$ also had difficulty in subsequently trying to conceive. Forty $(5 \cdot 2 \%)$ women had had no difficulty in becoming pregnant the first time but had problems subsequently, although 23 eventually conceived.

Of the 12 women who experienced both primary and secondary infertility, 11 had a recurrence of the problem in their second pregnancy and only four of these conceived. The remaining woman had no difficulty in conceiving in her second and third pregnancies but had tried unsuccessfully for a fourth. Delay in conceiving a second or third time accounted for most of those with secondary infertility only, although one woman attended hospital because of difficulty in conceiving for an eighth time despite already having four children.

\section{OCCUPATION}

The voluntary group included significantly more women whose present or usual occupation was professional or clerical (table III). This finding remained significant after correcting for multiple comparisons. Indeed, of the 14 women who were married and had chosen not to have children, 13 had professional or clerical occupations. The group with no infertility problems contained the smallest proportion of professional and clerical workers but the highest proportion of semiskilled and unskilled manual workers. The primary infertility group contained the highest proportion of women who had given their usual occupation as housewife.

PREGNANCY OUTCOME AMONG FERTILE AND INFERTILE WOMEN

Table IV shows the outcome of pregnancies for each group achieved by women who had become pregnant at some stage. The group with no infertility problems had the highest proportion of successful pregnancies and fewer spontaneous abortions and ectopic pregnancies than the other two groups. Though the secondary infertility group had the highest proportion of spontaneous abortions, the primary infertility group had the highest proportion of ectopic pregnancies and terminations.

Comparing the mean number of births, we found that the primary infertility group had 1.78 births, which was significantly fewer than either the secondary $(2 \cdot 25 ; t=2 \cdot 34 ; \mathrm{df}=79 ; \mathrm{p}<0 \cdot 01)$ or the no infertility

TABLE III - Women's usual occupation by infertility group. Values are numbers (percentages)

\begin{tabular}{lcccr}
\hline & \multicolumn{4}{c}{ Infertility group } \\
\cline { 2 - 5 } Occupation & $\begin{array}{c}\text { Primary } \\
(\mathbf{n}=68)\end{array}$ & $\begin{array}{c}\text { Secondary } \\
(\mathbf{n}=40)\end{array}$ & $\begin{array}{c}\text { Voluntary } \\
(\mathbf{n}=56)\end{array}$ & $\begin{array}{c}\text { None } \\
(\mathbf{n}=602)\end{array}$ \\
\hline Professional or clerical & $28(41)$ & $19(48)$ & $37(66)$ & $216(35 \cdot 9)$ \\
Distributive or skilled manual & $9(13)$ & $6(15)$ & $5(9)$ & $94(15 \cdot 6)$ \\
Semiskilled and unskilled manual & $11(16)$ & $8(20)$ & $5(9)$ & $159(26 \cdot 4)$ \\
Housewife & $20(29)$ & $6(15)$ & $3(5)$ & $126(20 \cdot 9)$ \\
None or not stated & & $1(3)$ & $6(11)$ & $7(1 \cdot 2)$
\end{tabular}

Excluding not stated: Primary $v$ voluntary $\chi^{2}=14 \cdot 84 ; \mathrm{df}=3 ; \mathrm{p} \leqslant 0 \cdot 01$

None $v$ voluntary $\chi^{2}=28.01 ; \mathrm{df}=3 ; p \leqslant 0.01$

Excluding not stated and housewives: None $v$ voluntary $\chi^{\prime}=18 \cdot 56 ; \mathrm{df}=2 ; \mathrm{p} \leqslant 0 \cdot 01$.
TABLE IV-Outcome of pregnancies in women who became pregnant for each infertility group. Values are total pregnancies for each possible outcome (percentages of women who experienced each outcome)

\begin{tabular}{|c|c|c|c|}
\hline \multirow[b]{2}{*}{ Outcome } & \multicolumn{3}{|c|}{ Infertility group } \\
\hline & $\begin{array}{c}\text { Primary } \\
(n=41)\end{array}$ & $\begin{array}{l}\text { Secondary } \\
(\mathrm{n}=\mathbf{4 0 )}\end{array}$ & $\begin{array}{c}\text { None } \\
(\mathrm{n}=602)\end{array}$ \\
\hline Births & $72(78)$ & $90(78)$ & $1524(88 \cdot 5)$ \\
\hline Spontaneous abortions & $13(14)$ & $21(18)$ & $151(8 \cdot 8)$ \\
\hline Ectopic pregnancies & $2(2 \cdot 2)$ & $2(1 \cdot 7)$ & $7(0 \cdot 4)$ \\
\hline Terminations & $5(5 \cdot 4)$ & $3(2 \cdot 6)$ & $40(2 \cdot 3)$ \\
\hline \multicolumn{4}{|l|}{ All pregnancies: } \\
\hline Total No & 92 & 116 & 1722 \\
\hline Mean No & $2 \cdot 2$ & $2 \cdot 9$ & $2 \cdot 9$ \\
\hline Range & $1-5$ & $1-5$ & $1-10$ \\
\hline
\end{tabular}

TABLE V-Proportion of infertile women who sought advice in each infertility group. Values are numbers (percentages)

\begin{tabular}{|c|c|c|c|}
\hline \multirow[b]{2}{*}{ Source of advice } & \multicolumn{2}{|c|}{ Infertility group } & \multirow[b]{2}{*}{$\begin{array}{c}\text { Total } \\
(\mathrm{n}=108)\end{array}$} \\
\hline & $\begin{array}{c}\text { Primary } \\
(\mathrm{n}=68)\end{array}$ & $\begin{array}{c}\text { Secondary } \\
(\mathbf{n}=40)\end{array}$ & \\
\hline None & $19(28)$ & $14(35)$ & $33(31)$ \\
\hline General practitioner only & $5(7)$ & $3(8)$ & $8(7)$ \\
\hline Hospital & $44(65)$ & $23(58)$ & $67(62)$ \\
\hline
\end{tabular}

group $(2 \cdot 56 ; t=4 \cdot 70 ; \mathrm{df}=641 ; \mathrm{p}<0 \cdot 01)$. Women in the secondary infertility group had more spontaneous abortions $(0.52)$ than the other two groups $(0.32$ and $0 \cdot 25)$, although this was significantly different from only the no infertility group $(t=2 \cdot 76 ; \mathrm{df}=640$; $\mathrm{p}<0 \cdot 01)$. Overall, the primary infertility group had the lowest mean number of pregnancies $(2 \cdot 2)$, compared with 2.9 in the second infertility group $(t=2.42$; $\mathrm{df}=79 ; \mathrm{p}<0.02)$ and with 2.9 in the no infertility group $(t=3 \cdot 04 ; \mathrm{df}=641 ; \mathrm{p}<0 \cdot 01)$.

\section{ATTENDANCE AT GENERAL PRACTICE OR HOSPITAL CLINIC}

Altogether, $67(8 \cdot 7 \%)$ (95\% confidence interval 6.7 to $10 \cdot 7 \%$ ) of the women who completed a questionnaire reported having attended a hospital because of infertility; a further $11(1 \cdot 4 \%)$ had consulted only their general practitioner. Three of the women who had consulted only their general practitioner were not included in our infertility groups because they had conceived well within two years and no referral had been made. Not all women classified as having infertility problems sought advice (table V). More women with primary infertility had attended hospital (44/68 $(64 \%))$ than those with secondary infertility $(23 / 40$ $(58 \%))$. In addition, five and three women in each group respectively $(8 \%)$ had consulted only their general practitioner.

Women who had given their usual occupation as housewife were more likely to have sought advice about their infertility problems, $20 / 26(77 \%)$ of them reporting either having consulted their general practitioner or having attended a hospital clinic. Those women who gave their occupation as professional or clerical were more likely to have sought advice (33/47 $(70 \%))$ than distributive and skilled manual workers $(9 / 15(60 \%))$ or unskilled manual workers $(12 / 19$ $(63 \%))$.

Overall $41 / 68(60 \%)$ women with primary infertility eventually conceived, as did $23 / 40(58 \%)$ of those in the secondary infertility group. There was no statistical difference, however, between the proportion who conceived according to whether the women had or had not sought advice (table VI).

\section{Discussion}

The need for information about the epidemiology of infertility has long been accepted, 121415 and the deficiencies of demographic data, particularly regarding the prevalence of secondary infertility, are well 
TABLE VI-Number (percentage) of women who actually became pregnant in each fertility group according to whether they consulted either their general practitioner or a hospital doctor, or whether they made no such consultation

\begin{tabular}{lcccccc}
\hline & \multicolumn{2}{c}{ Primary infertility } & & \multicolumn{2}{c}{ Secondary infertility } \\
\cline { 2 - 3 } \cline { 6 - 7 } & $\begin{array}{c}\text { Women who } \\
\text { consulted } \\
(\mathbf{n}=49)\end{array}$ & $\begin{array}{c}\text { Women who did } \\
\text { not consult } \\
(\mathbf{n}=19)\end{array}$ & & $\begin{array}{c}\text { Women who } \\
\text { consulted } \\
(\mathrm{n}=26)\end{array}$ & $\begin{array}{c}\text { Women who did } \\
\text { not consult } \\
(\mathrm{n}=14)\end{array}$ \\
\hline $\begin{array}{l}\text { Pregnancy achieved } \\
\text { Pregnancy not achieved }\end{array}$ & $\begin{array}{l}28(57) \\
21(43)\end{array}$ & $\begin{array}{c}13(68) \\
6(32)\end{array}$ & & $\begin{array}{c}16(62) \\
10(39)\end{array}$ & $7(50)$ \\
\hline
\end{tabular}

recognised. ${ }^{16-18}$ To our knowledge this is the first community based survey of infertility in the United Kingdom since Matthews Duncan described his work in the villages of Grangemouth and Bathgate over 100 years ago. ${ }^{19}$

Our first conclusion is that a community based survey of this sort is feasible, is relatively easily organised, and can yield important information. Our response rate of $85.7 \%$ was similar to that reported in a recent pilot study from Sheffield (82\%) and higher than that of an interview based study of the prevalence of infertility in Denmark (74\%). ${ }^{120} \mathrm{We}$ found that $12 \%$ of those to whom the questionnaire was originally posted were not at the address given, a figure compatible with the $10 \%$ error contained in general practitioner age-sex registers. ${ }^{21}$

The overall rate of infertility (14\%) was similar to that reported in a questionnaire based study carried out in Melbourne, ${ }^{22}$ more than that in a survey based on general practice medical records, ${ }^{3}$ but less than that estimated on the basis of fecundability calculations. ${ }^{6}$ In the Danish study about $9 \%$ of women had primary infertility (defined as trying to conceive for two years, as in this study) and a further $9 \%$ had secondary infertility. ${ }^{14}$ Perhaps the best available data on the epidemiology of infertility has been derived from the United States national survey of family growth. ${ }^{1323}$ Surveys were carried out in 1965, 1976, and 1982, and the last survey found that $13.9 \%$ of currently married women aged 15-44 who were not surgically sterile were infertile. Of these, $30 \%$ had primary infertility and $70 \%$ secondary infertility. This contrasts with our findings for an older five year cohort of $63 \%$ and $37 \%$ respectively.

The prevalence of voluntary infertility was much less than we had expected, and less than had been estimated in a previous study in the same region. ${ }^{24}$ Individual attitudes to childbearing vary and might be dependent on many factors including age, family circumstances, prevailing social custom, and social class. The voluntarily infertile group was the only one that differed statistically from the other groups, both fertile and infertile, with regard to social class; it contained a significantly higher proportion of women in professional and clerical occupations. It was not known whether they had elected to remain childless because of careers or whether being childless had facilitated their occupational advancement.

Just over half of the infertile women in this study eventually became pregnant, a rate similar to the eventual outcome in the Danish survey. ${ }^{20}$ Not unexpectedly, the pregnancy outcome among the infertile women who eventually became pregnant was different from that of the fertile group. The most striking difference was the high proportion of spontaneous abortions in both infertile groups; the overall rate among infertile women was almost double that among women who had no infertility problems. A high abortion rate among infertile women has been reported, ${ }^{2022}$ although it has been suggested that this might be partly due to underrecording among the fertile population. ${ }^{25}$ Nevertheless, several clinical studies have continued to show that spontaneous abortion is more common among certain subgroups of infertile women, particularly those with secondary infertility. ${ }^{26}{ }^{27}$ Loss of pregnancy is clearly of particular importance to infertile couples, and this problem merits further study.

Much of what is known about the characteristics of infertile men and women has been derived from clinic based data, but this study has shown that not all women with infertility attend a hospital or their general practitioner. The motivation for seeking advice is uncertain and will be the subject of further research. Meanwhile, it was of interest that housewives and women who had professional or clerical jobs were more likely to use the services. Studies from other countries have reported an even lower uptake of hospital services than that reported here and, indeed, have shown that most women do not seek medical advice. ${ }^{1314}$ Both the Danish and the American studies, however, did confirm a greater use of services among women with primary infertility, though, in the American study particularly, there were sharp social differences (mainly higher income and education) among women with secondary infertility who made use of the services. ${ }^{13}$ Thus, regardless of whether the incidence of infertility is increasing, a higher proportion of infertile women will probably attend clinics in future because of their greater awareness and expectations of treatment.

Although we cannot comment on any change in the incidence of infertility from our study, it might be possible to do so by surveying cohorts of a younger age using the same method. The incidence of infertility is often said to be increasing, but there is little evidence that this is so, ${ }^{323}$ even though the incidence of the associated conditions of pelvic infection and ectopic pregnancy has increased. ${ }^{28-33}$ Population based surveys of this kind are probably the only reliable way that changes in the incidence of infertility may be recorded.

Finally, we studied whether those infertile women who eventually conceived were more likely to have made use of the medical services available, but it did not appear that this was so. Clearly there might have been differences among the groups in the duration of infertility, which is known to have a major effect on prognosis, though the occurrence of a high incidence of pregnancies independent of treatment among infertile women is well established. ${ }^{934}$ Studies of younger women who have been investigated and treated more recently may, however, provide some evidence of the effectiveness of the medical services.

We are grateful to $\mathrm{Mr}$ Powe, administrator, Primary Care Division, for help and access to the primary care register.

1 Department of Health and Social Security. Report of the Committee of Inquin into Human Fertilisation and Embryology. London: HMSO, 1984. (Warnock into Human

2 Page $\mathrm{H}$. Estimation of the prevalence and incidence of infertility in a population: a pilot study. Fertil Steril 1989;51:571-7.

3 Johnson G, Roberts D, Brown R, et al. Infertile or childless by choice? A multipractice survey of women aged 35 and 50. Br Med $\mathrm{f}$ 1987;294:804-7. Office of Population Censuses and Surveys. General Household Survey 1987. (Series GHS.) London: HMSO, 1989.

Vessey M, Wright NH, McPherson K, Wiggins P. Fertility after stopping different methods of contraception. Br Med J 1978;i:265-7.

6 Spira A. Epidemiology of human reproduction. Hum Reprod 1986;1:111-5.

7 Howe G, Westhof C, Vessey M, Yeates D. Effects of age, cigarette smoking, and other factors on fertility: findings in a large prospective study. Br Med $\mathcal{J}$ 1985;290: $1697-700$.

8 Newton J, Craig S, Joyce D. The changing pattern of a comprehensive infertility clinic. F Biosoc Sci 1974;6:477-82.

9 Templeton AA, Penney CC. The incidence, characteristics, and prognosis of patients whose infertility is unexplained. Fertil Steril 1982;37:175-82.

10 Hull MGR, Glazener CMA, Kelly NJ, et al. Population study of causes, treatment, and outcome of infertility. Br Med f 1985;291:1693-7.

11 Haxton MJ, Black WP. The aetiology of infertility in 1162 investigated axton MJ, Black WP. The aetiology of infer
couples. Clin Exp Obstet Gynecol 1987;14:75-9.

2. Aral SO, Cates W Jr. The increasing concern with infertility. Why now? JAMA 1983;250:2327-31.

3 Hirsch MB, Mosher WD. Characteristics of infertile women in the United States and their use of infertility services. Fertil Steril 1987;47:618-25.

4 Rachootin P, Olsen J. Social selection in seeking medical care for reduced fecundity among women in Denmark. I Epidemiol Community Health 1981;35:262-4. 
15 Hastings DW, Robinson JG. Incidence of childlessness for United State women, cohorts born 1891-1945. Soc Biol 1974;21:178-84

6 McFalls JA, McFalls WH. Diseases and fertility. New York: Academic Press, 1984.

17 Belsey MA. The epidemiology of infertility: a review with particular reference to sub-Saharan Africa. Bull WHO 1976;54:319-41.

18 Sherris JD, Fox G. Infertility and sexually transmitted disease: a public health challenge. Popul Rep 1983;XI:113-51.

19 Duncan JM. Fecundity, fertility, and sterility. Edinburgh: A and C Black, 1866.

20 Rachootin P, Olsen J. Prevalence and socioeconomic correlates of subfecundity and spontaneous abortion in Denmark. In $\mathcal{f}$ Epidemiol 1982;11 fecun 9 .

21 Fraser RC, Clayton DC. The accuracy of age/sex registers, practice medical records and family practitioner committee registers. $f R$ Coll Gen Pract 1981;31:410.

22 Young $C M$. The role of medical factors in the failure to achieve desired family size. F Biosoc Sci 1979;11:159-71.

23 Mosher WD. Infertility trends among United States couples: $1965-1976$ Fam Plann Perspect 1982;14(1):22-7.

24 Porter M. Infertility: the extent of the problem. Biology and Society 1984; $128-35$

25 Miller JF, Williamson E, Glue J. Fetal loss after implantation: a prospective study. Lancet 1980; i:554-6.

26 Pittaway DE, Vernon C, Fayex JA. Spontaneous abortions in women with endometriosis. Fertil Steril 1988;50:711-5.
27 Jensen PS. Spontaneous abortion incidence in the treatment of infertility Am f Obstel Gynecol 1982;143:451-73.

28 Templeton AA. Female infertility and pelvic infection. In: MacLean AB, ed. Clinical infection in obstetrics and gynaecology. Oxford: Blackwell Scientific Publications (in press)

29 Westrom L. Incidence, prevalence, and trends of acute pelvic inflammatory disease and its consequences in industrialised countries. Am 7 Obstet Gynecol $1980 ; 180: 880-92$.

30 Aral SO, Holmes KK. Epidemiology of sexually transmitted diseases. In Holmes KK, Mardh PA, Sparling PF, Wiesner PH, eds. Sexually transmitted diseases. New York: McGraw Hill, 1984:127-41.

31 Westrom L, Bengtsson L, Mardh PA. Incidence, trends, and risk of ectopic pregnancy in a population of women. Br Med f 1981;282:15-8.

32 Rubin GL, Peterson HB, Dorfman SF, et al. Ectopic pregnancy in the United States 1970 through 1978. JAMA 1978;249:1715-29.

33 Flett GMM, Urquhart DR, Fraser C, Terry PB, Fleming JC. Ectopic pregnancy in Aberdeen 1950-1985. Br f Obstet Gynaecol 1988;95:740-6.

34 Bernstein D, Levin S, Amsterdam E, Insler V. Is conception in infertile couples treatment-related? A survey of 309 pregnancies. Int $\mathcal{f}$ Fert 1979;24:65-7.

35 Collins JA, Wrixon W, Janes LB, Wilson EH. Treatment-independent pregnancy among infertile couples. $N$ Engl I Med 1983;309:1201-6.

(Accepled 30 April 1990)

\section{General practitioners' awareness of colorectal cancer: a 10 year review}

\author{
A R Dixon, J Thornton-Holmes, \\ Nicolette $M$ Cheetham
}

\section{Peterborough District Hospital, Peterborough PE3 6DA}

A R Dixon, FRCS, registrar J Thornton-Holmes, FRCS, consultant surgeon

\section{Leicester LE2 6TD}

Nicolette $M$ Cheetham, MRCGP, general practitioner

Correspondence to: $\mathrm{Mr}$ A R Dixon, Professorial Unit of Surgery, City Hospital, Nottingham NG1 5PB.

BrMed f 1990;301:152-3 past decade.

\section{Patients, methods, and results}

The prognosis of colorectal cancer, largely determined by the extent of spread of the tumour at diagnosis, ' has remained unchanged for three decades, probably because patients continue to present with tumours at an advanced stage. $^{2}$ In 1968 a third of patients presented within three months of developing symptoms, though a quarter had had symptoms for over a year. ${ }^{3}$ These figures remained unchanged a decade later. ${ }^{4}$ Delays are attributable to both the patient and the family doctor. We undertook a study to assess referral patterns and the delay in diagnosis over the

We reviewed the case notes and general practioners' referral letters for all 376 patients electively treated by right hemicolectomy, anterior resection, or abdominoperineal excision of the rectum by one firm between 1978 and 1988. Data collected included the general practitioner's diagnosis, duration of symptoms, physical signs, investigations, and time between referral and operation.

The patients were referred by 151 general practitioners. Altogether 202 tumours were suitable for an anterior resection, 85 required an abdominoperineal excision of the rectum, and 89 required a right hemicolectomy. The median age at presentation was 67 (range 31-91). The mean interval between the development of symptoms and outpatient assessment was 16 weeks for tumours sited on the left side (range four days to two years) and 27 weeks for those on the right side (2-28 months). Surgery was performed at the next available list; the median interval was 20 days (3-27 days). Twenty barium enemas were requested by the general practitioners, and all gave positive results. Fourteen patients had barium examinations at the request of surgeons, which gave inconclusive results. Rigid sigmoidoscopy yielded a diagnosis in 150 patients.

The presenting symptoms of the 287 patients with left sided tumours comprised alteration in bowel habit (212 patients), rectal bleeding (169), and abdominal pain (126). Perineal discomfort or swelling occurred in
40 , weight loss in 34 , symptomatic anaemia in 12 , abdominal swelling in six, and disturbed micturition in four.

Of the 202 patients who had an anterior resection, 143 were seen within two weeks of receipt of a referral letter that stated or suggested that the diagnosis was cancer. The remaining patients had symptoms attributed to diverticulosis (28), haemorrhoids (12), or the irritable bowel syndrome (eight) or were referred without a diagnosis (11). Rectal examination showed 136 carcinomas, 64 of which had been noted by the general practitioner. Twelve patients with easily palpable tumours were referred without having had a rectal examination.

Of the 85 patients requiring abdominoperineal excision of the rectum, 59 were referred with the correct diagnosis and a referral letter that stated that a carcinoma was palpable. Despite apparently normal results of rectal examination 11 patients were referred for urgent investigation of a possible malignancy. Fifteen patients were referred with haemorrhoids without having had a rectal examination; these patients were seen routinely, leading to a further median delay of nine weeks.

The general practitioners' letters suggested a diagnosis of malignancy for 77 of the 89 patients treated by right hemicolectomy; 68 suggested that the carcinoma was caecal. The mean duration of symptoms was 27 weeks (range 2-28 months). Symptoms described included symptomatic anaemia (46 patients), abdominal pain (46), abdominal mass (36), and weight loss (12).

\section{Comment}

In 1968 the delay from the onset of symptoms until treatment was seven and a half months, increasing to nine months for rectal malignancies. ${ }^{3}$ As a consequence of this delay $19-42 \%$ of patients required emergency surgery,,$^{24}$ three quarters of them having consulted their doctor about symptoms. ${ }^{4}$ Once symptoms have occurred a delay in diagnosis does not necessarily have a detrimental effect on survival ${ }^{34}$ unless emergency surgery becomes mandatory. Emergency surgery is associated with a mortality of $24 \%$ compared with the $3.6 \%$ associated with elective procedures.

Holliday and Hardcastle attributed delays to patients not understanding the importance of bowel symptoms and the failure of general practitioners to recognise symptoms of colorectal carcinoma and to examine patients adequately $: 22 \%$ of patients with rectal cancer had had no rectal examination before referral. When general practitioners were questioned about factors that might cause a delay in referring patients $40 \%$ said 